\title{
Security Challenges of Small States
}

\author{
Bhimnath Baral
}

\begin{abstract}
The concept of Security has a vital role in the study of international relations. This concept is old as human civilization. It has different meaning in different phases of history. However, there have been sea changes in the interpretation of security matters. The traditional statecentric security has transferred into modern human centric approach. But the small states are always threatened by it in different forms and nature. As a precondition for sustainable political, economic and social development, small states are always tortured by several internal and external factors. So, this article overviews about the various security challenges faced by small states.
\end{abstract}

Keywords: Dependency, geostrategic, globalization, human centric, state- centric.

\section{Introduction}

The concept of security is taken as the most sensitive and important issue for every individual, society and country as well. The topic has differently defined by various social scientists, security scholars and ordinary people in their own way. There are many interpretations of security concept and each carries separate explanations to different actors and conditions. Though the concept has its origin as old as human civilization, still it lacks universal definition. Very few literatures deal with the concept of security. Mostly the existing literature focuses on the empirical side dealing with contemporary security problems and issues that analyze the foreign and military policies of state (Wagle, 2010:220). So, it is also found that the concept is viewed through military centric approach from the eyes of a 
state. However, the trend of analyzing the concept has changed after the disintegration of Soviet Union in the early 1990s. This period witnessed the significant decreas of inter-state war and contributed in reduction of traditional security threats (Bhattarai, 2010:28). Its interpretation is made beyond the traditional definition of protection of state.

No doubt, protection of sovereignty, territorial integrity and political independence are the fundamental security concerns of every state. It was in rigid form in traditional state system and is equally important even in modern world order. Even in the recent past, the concept of security was narrowly defined. With the span of time, its meaning touches new height and is widened. Modern concept of security is no more state-centric. The concept is added with several new dimensions. The conventional statecentric dimension is now added with human-centric dimension (Mantoo, 2016:68). Human beings now are facing with a large number of non-traditional threats like poverty, illiteracy, malnutrition, child labor, drug trafficking, environmental degradation, civil war and so on.

Comparatively, the small state like Nepal has to face several external and internal security challenges. Though the end of cold war has to some extent stopped the global competition for super power status and has left the small states especially those belonging to the developing world. The small states in the Third World are no longer pawns in their power play (Khanal, 2010:96). There are several examples of small states being victimized by big power from the hegemonic design of their neighbors. The Gulf War just after the collapse of soviet Bloc in early 1990s, continuous Afghan War and annexation of Crimea in Russia are some examples of security threats of small states. On the one hand, these states are threatened by external factors which are 
still considered on the danger for the survival of the state. On the other, they are unable to tackle with internally created threats for security, which have long lasting effect in their existence.

The principal objective of this article is to explore the security challenges of small states. It has also the aim to highlight the various security issues and their impacts on small states as the threats for their survival. Further, the article is designed with descriptive and analytical methods since it has aimed to explore the various security challenges that are being faced by small states. The facts and data of this article are based on secondary sources and they are mostly qualitative is nature.

\section{Theoretical Aspect of the Security}

Civilization witnessed that human society has to tackle with many security threats. But the concept of security is very much contested and there is no agreement among security expects regarding its meaning. The concept is equally contested in case with its theoretical understanding. There are many security related theories which have been put forwarded by many theorists and each theory differs in understanding the theoretical aspects of security. As a field of inquiry Paul D. Williams, a famous scholar in security studies, has raised four fundamental questions to be known like, What is security? Whose security are we talking about? What counts as a security issue? and how can security be achieved? (Williams, 2012:5) . In course of shaping the concept, various theories have been developed in this field. The notable theories like realism, liberalism, game theory, constructivism, peace studies, and political sociological theory have their own perspectives regarding security. However, there are two main approaches about the security i.e. Realism and Welsh school of critical theory (Mantoo,2016:69).

Realism is a multifaceted and durable tradition of inquiry in 
security studies (Elman,2012:26). The realists assume that the desire for more power is rooted in the flawed nature of humanity. So states are continuously engaged in a struggle to increase their capabilities. The traditional realists are the central contributor to security studies. All the realists believe that the international system is anarchic because there is no authority above the state and the state is the main actor at global level. Furthermore, realism sees security studies as the conditions that make the use of force more likely the way that the use of force affects individuals, states and societies, and the specific policies that state adopt in order to prepare for, prevent or engage in war (Mantoo, 2016:70). This school of thought argues that the referent of security is the state and it is the primary provider of security (Wagle, 2010:221). State and military-centric approach of security mainly focuses on the issue that is related with sovereignty, territorial integrity and political independence of a country.

On the contrary, the Welsh school of thought views security through human-centric approach. This thought regards security as emancipation (William, 2012:6). It denotes the freeing of people (as individual and groups) from physical and human constraints which stop them carrying out what they would freely choose to do (Mantoo, 2016:71). Modern international relations highly focus on human-centric security variables. Fen Osler Hampson classifies such concept into three distinct conceptions i.e natural rights/rule of law conception of human security, humanitarian and economic security (Hampson, 2012: 230231). The first category of security lies upon the fundamental life, liberty and the pursuit of happiness. The second concept tends to protect humanity discouraging war, weapons and crimes. The last concept covers a broader view than that of the previous views. The wider areas like economic, environmental, Security Challenges... Bhimnath Baral - 4 - 
social and other forms of harms to overall livelihood and wellbeing of individuals are included in this conception of security. The security scholars like John T. Picarelli have pointed out increasing transnational organized crime including illicit trade of drugs, people and arms as the emerging security challenges of present day world (Picarelli, 2012: 453-457). On the whole, the fundamental difference in classical and modern security conception can be viewed in the given table.

\section{Comparison: Traditional State-centered Versus Human- centered Security}

\begin{tabular}{|l|l|l|}
\hline & $\begin{array}{l}\text { Traditional } \\
\text { (Realists and Neo- } \\
\text { realists Vision) }\end{array}$ & $\begin{array}{l}\text { Non- traditional (Human Centered } \\
\text { Security) }\end{array}$ \\
\hline $\begin{array}{l}\text { Security } \\
\text { referent } \\
\text { (object) }\end{array}$ & $\begin{array}{l}\text { In a Hobbesian } \\
\text { world, the state is } \\
\text { the primary provider } \\
\text { of security: if the } \\
\text { state is secure, then } \\
\text { those who live } \\
\text { within it are also } \\
\text { secure. }\end{array}$ & $\begin{array}{l}\text { Individuals are co-equal with the } \\
\text { state. State security is the means } \\
\text { not the end. }\end{array}$ \\
\hline $\begin{array}{l}\text { Security } \\
\text { value }\end{array}$ & $\begin{array}{l}\text { Sovereignty, power, } \\
\text { territorial integrity, } \\
\text { national } \\
\text { independence }\end{array}$ & $\begin{array}{l}\text { Personal safety, well-being and } \\
\text { individual freedom } \\
\text { 1. Physical safety and provision } \\
\text { for basic needs; } \\
\text { 2. Personal freedom; } \\
\text { 3. Human right; economic and } \\
\text { social rights }\end{array}$ \\
\hline
\end{tabular}




\begin{tabular}{|c|c|c|}
\hline $\begin{array}{l}\text { Security } \\
\text { Threats }\end{array}$ & $\begin{array}{l}\text { Direct organized } \\
\text { violence from other } \\
\text { state, violence and } \\
\text { coercion by other } \\
\text { states and from } \\
\text { non-state actors }\end{array}$ & $\begin{array}{l}\text { Direct violence: death, drug, } \\
\text { dehumanization, discrimination, } \\
\text { international disputes, WMD; } \\
\text { gendered violence } \\
\text { Indirect violence: deprivation } \\
\text { diseases, natural disasters, } \\
\text { underdevelopment, population } \\
\text { displacement, environmental } \\
\text { degradation, poverty, quality, } \\
\text { ethnic/sectarian oppression }\end{array}$ \\
\hline & $\begin{array}{l}\text { Traditional } \\
\text { (Realists and Neo- } \\
\text { realists vision) } \\
\end{array}$ & $\begin{array}{l}\text { Non-traditional (human centered) } \\
\text { security }\end{array}$ \\
\hline $\begin{array}{l}\text { By what } \\
\text { means }\end{array}$ & $\begin{array}{l}\text { Retaliatory force } \\
\text { or threat of its use, } \\
\text { military means, } \\
\text { strengthening of } \\
\text { economic might, } \\
\text { little attention paid } \\
\text { to respect for law } \\
\text { or institutions. }\end{array}$ & $\begin{array}{l}\text { Promoting human development: } \\
\text { basic needs plus equity, } \\
\text { sustainability, and greater } \\
\text { democratization and participation } \\
\text { at all levels. Promoting human } \\
\text { rights Promoting political } \\
\text { development: global norms and } \\
\text { institutions plus collective use } \\
\text { of force as well as sanctions in } \\
\text { case of genocide, cooperation } \\
\text { between states, reliance on } \\
\text { international institutions, networks } \\
\text { and coalitions and International } \\
\text { organizations. }\end{array}$ \\
\hline
\end{tabular}

Source: Bhattari, $2070: 27-28$

\section{Challenges of Small States}

Security is considered as the fundamental concept at both local and global level. The present day world is the era of globalization Security Challenges... Bhimnath Baral - 6 - 
and the question of security has emerged in new form and character. The security paradigm shall be understood for practical purposes so that meaningful international relations and security studies can help to manage a safer place for mankind.

But the small states are much more affected by several forms of security threats. Though all the small states are not equally vulnerable in the global system, still the degree of threat seems higher in their case. Some small states in the world can manipulate the interests of the bigger states because of their glorious tradition and the wealth they possess due to the availability of rare resources and their diplomatic capability. But many of them, especially the ones belonging to the developing world, are facing a variety of security challenges from within and outside the country. Such challenges can broadly be classified as; a) Internal security challenges b) External security challenges

\subsection{Internal Security Challenges}

The eastern thinker Kuutilya in his book 'Arthashastra' has written that a state could be at risk from four types of challengesinternal external, externally aided internal and internally aided external (Mantoo, 2016:70). He further said that internal challenges should be taken care immediately. According to him, the most dangerous enemy is the enemy within. Mahabharat, the holy Hindu epic, also tells that internal conflict is the cause of destruction. Most small states at international environment are the victim of internal challenges. The followings are the common problem that the small states may face as internal challenges to their national and human security:

\subsubsection{Political Instability}

Most of the small states have an experience of long-run political instability. Many of the small states were under the colony of big 
powers during their early days of political development. Even after the independence, only a very few of them could catch the right track of political development and institutionalized their political system. The developing world is usually insufficient and ineffective in political matters. Dominating role of few political elites, bad governance, lack of rule of law, unable to maintain law and order, failed to maintain peace and security (Khanal: 2010: 102) are the main reasons of political challenge.

\subsubsection{Cultural Challenge}

The issue of ethnicity is a burring problem of today's world. With the commencement of $21^{\text {st }}$ century, many people had thought that the world would be a safer place to live in with no power struggle between the two super powers as cold war has already ended. But in reality, the internal problems among the peoples of different states had not yet ended. The fight among different nationalities and cultures caused disintegration of Soviet Union, Yugoslavia and Sudan. The small political entities emerged in the world on the basic of ethnicity and cultural groupings started fighting to control territories on ethnic and cultural lines (Khanal, 2010: 100). The countries of Asia, Africa and Latin America having cultural pluralism have violent ethnic clashes. Ethnonationalism emerged in small states like Nepal is challenging the survival of the nation. Similarly the religion, language and caste is considered as the another security threat. Religious fundamentalism became the cause of division of India and Pakistan, and Pakistan and Bangladesh. Ethno-nationalist movements not only posed a challenge to national sovereignty but also stability of the international system (Mingst, 2004: 133). Many countries failing to address the ethnicity problem are facing the security problem from inside . 


\subsubsection{Economic Challenge}

Most of the small states have poor economy. Poverty, unemployment, trade deficit, and poor technology are some of the common characteristics of small states. Dependency is high and most of their policies are guided by other's interest. Weak infrastructures, less use of resources and regional imbalance in terms of development are the major sources of conflict that may pose serious security threat to the small countries (Khanal, 2010: 101). Many of the revolution that have taken place in the world around were caused because of economic disparity. Economic factor is found more responsible behind the outbreak of civil war in many countries especially the developing ones.

\subsubsection{Environmental Challenge}

One of the issues that has greatly been affecting the security is the growing environmental challenges that the country is facing (Bhattarai, 2010: 50). Degradation of shared rivers global warming, increasing urbanization, deforestation, rise in the level of the sea, partial rain, drought, etc. have a direct challenge upon the lives of the world. Basically, the small states are unable to avoid the coming challenges because of environmental issues. Global warming and the climate change are major concerns and even in a small county like Bhutan where in spite of a successful protection of the environment, signs of climate change are becoming visible (Kelegama, 2011: 106). Sustainable development of the country is impossible without maintaining environmental sustainability which has direct impacts on other aspects of development.

\subsubsection{Forced Migration}

Yet, there is another serious threat for the small and poor countries because of increasing migration. On the one hand, there is the 
flow of migrating people from rural areas to urban areas due to insecurity, unemployment, extreme climate and so on. The trend was more during the period of armed revolution (2052-2063 BS). Many of them fled to India and other countries. On the other hand, there is the continuous outflow of trained and skilled human power in different parts of the world in search of work and study. Those who are working in other countries as Bahadur and Kanchha are shedding their sweat for the development of other's countries. High mobility of migrating people also causes the trafficking of women and children, commercial sex, drug trafficking and high rate of HIV/AIDS (Mantoo, 2016: 74). These all have created a serious threat in national development.

\subsubsection{Geo-strategic Location}

Geographical location of a country has a great influence in geopolitical determinance. Some small states which have no geographical significance can have nominal role in world politics. But at the same time some countries like Nepal can play the role of buffer state between two contending powers. Such location can be both opportunity and challenge for small states. Differences in culture, language, race, pace of development, governmental system, etc. may add the challenges for a country like Nepal.

Most landlocked countries also fall under small state category. Their freedom of action is limited by landlockedness (Subedi, 2010: 80). Such landlocked states are unable to interact freely in the global environment because of their landlocked nature. Apart from exceptions like Switzerland and Austria, many landlocked countries often become the playground of big powers which always remain as the threat to their survival and national development as well. 


\subsubsection{Erosion of Nationalism}

Nationalism is taken as the glue of national unity. It is more vital in a country having divergent caste, race, language, tribe, ethnicity and culture. These factors may be the threat to sovereignty and integrity of the nation and difficult to hold the nation together (Subedi, 2010: 84). This is especially so for strategically located states such as Nepal where there is no longer any centre gravity and population is so diverse.

\subsection{External challenge}

Every state is an important unit of global system. The small states have their impact in the working of United Nations Organization and other global and regional forums because of their numerical strength and the rare resources they pose. Still they exhibit a low level of participation in world affairs and rely on superpowers for protection, partnership and resources (Hey, 2003: 5). So the small states have to tackle with several external challenges.

\subsubsection{Global Rivalry}

History noticed that international politics has remained the big power game where the small states have a very few roles to play. The cold war and post-cold war international system is characterized by power seeking tendency on which the small power become the victim. The small power like Hungary, Afghanistan, Vietnam, etc. had faced the threat of national security from big powers i.e. Soviet Union, USA and so on. The Gulf War of early 90s, annexation of Crimea is Russia, Afghan War, Syrian Civil War, etc. are the outcome of big power competition. Since the onset of the cold war many external factors have used the Nepali soil for all sorts of activities including espionage (Subedi, 2010: 81). The small states often become the victim of unhealthy competition of external powers. 


\subsubsection{Aid Dependency}

Though modern international system is characterized by interdependency nature, however old dependency concept still exists in reality. Most small states rely on big powers for their development. Such compulsion has given birth to new colonialism and the small countries are forced to adopt the policy to suit the intension of donor country. Increasing role of multinational corporation and monopolization of international financial institutions have increased economic disparity and small states today are experiencing economic exclusion. All these have promoting dependency. It is the deprivation of small state's participation in the international financial architecture, which has not only threatened the economic sovereignty but also made them vulnerable in their security perceptions (Khanal; 2010: 106). The aid funded development activities always remain challengable for poor and small states.

\subsubsection{Globalization}

Globalization is the emerging trend of international relations. Free flow of idea, information, technology, investment, trade, tourism, goods and services have crossed the state boundary. It is mainly because of the tremendous progress in the field of transportation and communication. Such boundary-less situation has become the threat to small nations and they are not able to catch the opportunities brought by globalization. Though several agents of globalization like World Bank, IMF, and MNCs are working to boost up the condition of developing nations, but these agencies are often being criticized as the agents of new colonialism (Baral;2017:182). It has equal threat upon tradition, culture, religion and indigenous products as well. 


\subsubsection{Weak Diplomacy}

Diplomacy is the process by which foreign policy goal is carried out. It is the agency through which foreign policy seeks to attain its purpose by agreement rather than by war. The small states having poor bargaining power can best serve their interest only through diplomatic dealing. They can attract the big power through an effective diplomacy at the time of national crisis and save themselves from the possible disasters. Countries like Switzerland, Austria and Singapore had managed to remain aloof in the major conflict through diplomatic measures (Khanal, 2010: 108). But most of the small powers have poor performance in diplomatic dealings. Marginalization of the role of Ministry of Foreign Affairs, poor job satisfaction, lack of public support, absence of clear-cut foreign policy behavior, poor information, reactive behavior and lack of experienced and patriot diplomat have added the challenges in foreign policy matters. Immature diplomacy always threatens national security.

\subsubsection{Current World Environment}

Small state's security matter is also challenged by world environment. The role of international organization, world public opinion and country's approach with other nation are some external challenges for security of the small states. The world condition is also responsible to create challenges. The world situations i.e. tense or relaxed, cold war like or detente like, war prone or peace oriented etc. to many extent create the challenges. Indo-Pak tension has added security threats in South Asia where as the tension in North Korea has added more security threats in the far-east region. 


\subsection{Challenge to Human Security}

There have been sea changes in traditional concept of security of state. No doubt, small states are always worried in regard to protect their vital interest i.e protection of sovereignty, territorial integrity and political independence. The world scenario is not found friendly to them because of various internal and external factors as mentioned earlier. In spite of all these, new issues have emerged in international relations and world community has to pay adequate eyes to fight against the new form of security challenges. The idea of human security challenges the traditional notion of national security which seeks to shift the referent of security away from the state to individual (Picarelli, 2012: 464). The UN special adviser, Mahbub-ulHaq, who is credited with the authorship of the first UN Human Development Report, formulated the concept of human security (Ahmed, 2011: 135). It is the fourth wave of the future which is based on more comprehensive security framework (Pandey, 2008: 5). It is premised on the assumption that national, regional and global stability should be based on a people-centered view of security. Respect for human right to protect human dignity, basic needs for survival i. e. food, shelter, clothes, education, health, employment, ethnic rights, women's right, refugees, drug trafficking, human trafficking, crime, terrorism, HIV AIDS, environmental degradation, arm race, nuclear proliferation, inclusion, participation and several other issues are emerging as new security challenges. Small states are struggling hard to override these threats. Many states are failed to manage the issued and are the victims of instability, civil war and social disorder. 


\section{Conclusion}

The concept of security is as old as the origin of civilization. It is very important and sensitive issue. Neither in the past nor in future, society can ignore it. But there have been sea changes in the concept of the subject. The beginning of $21^{\text {st }}$ century brought a new hope and new understanding for global peace, cooperation and development. The security paradigm should be understood for practical purposes so that friendly relation can help to build a safer world for mankind not confined to one nation state or regional bloc of nations.

The small states are challenged by several internal and external factors in their security. The external factors like weak diplomacy, aid dependency, international environment, globalization, global rivalry and cultural diversities, social backwardness, geo-strategic location, poverty, environmental degradation, migration, and erosion of nationalism are standing as the major security threats for small states. Their vulnerabilities and their weakening position today mainly come from the internal factors although some external roles can't be denied.

Security is, of course, a precondition for sustainable economic, social and political development. Investment of scarce resources to unproductive activities such as purchases of military equipments has negleted the social and human security. Such tendency creates poverty, unemployment and several other humanitarian problems which led to the rise of extremism and as a result, violence and instability occur in the society. Security is the most commonly associated with the alleviation of threats. These threats more often come from human-centric factors. So, modern security scholars have paid more focus to human-centric factors for sustainable peace and stability in the world. 


\section{References}

Baral, Bhimnath (2017). Globalization and its Impacts on developing nations including Nepal in Pragyik Prabhaha, vol, VI Pokhara: Faculty of law, Prithivi Narayan Campus, Tribhuvan University, Pokhara, Nepal.

Bhattarai, Rajan (2010). Broadening Nepal's security agenda: Armed conflict, migration and environmental perspectives in emerging security challenges of Nepal edited by Rajan Bhattarai and Geja Sharma Wagle, Kathmandu: Nepal Institute for policy studies_ (NIPS).

Dahal Devraj (2001). Geopolitics of Nepal: Survival strategies of a small state in the political economy of small states, edited by Ananda Aditya, Nepal Foundation for advanced studies (NEFAS), friedrich- Ebert- stiftung (FES).

Elman, Coline (2012). Realism in security studies, edited by Paul D Williams, New York: Routledge Taylor and Francis group.

Hampson, fen Osler (2012). Human security in security studies edited by Paul D Williams, New York: Routledge Taylor and Francis Group.

Hey, Jeanne A.K. (2003). Introducing small state foreign policy in small states in world politics explaining foreign policy behaviour, edited by Jeanne A.K.Hey, Colorado: Lynne Rienner Publishers, Inc.

Ishtiaq, Ahmed (2011). SAARC Social charter and human security in the emerging dimentions of SAARC, edited by S.D. Muni, Cambridge, University Press. India, Pvt. Ltd.

Khanal, Rabindra (2010). Security of small states in Journal of Political Science, vol XII, No.2 Central Department of Political Science Tribhuvan University, Kritipur, Kathmandu, Nepal.

Kelegama, Saman (2011). SAARC energy cooperation: energy security and environmental challenges in the emerging dimensions of $S A A R C$, edited by S.D. Muni, Cambridge, University Press. India, Pvt. Ltd. 
Mantoo, Shahanawaz (2016). Internal and external security challenges of Nepal, In Foreign Policy of Nepal and Her Neighbors, edited by Pramod Jaiswal and Geeta Kochher, New Delhi: Smt Neelam Batra, G. B. Books publishers and Distributors.

Mingst, Karen A. (2004). Essentials of international relations, $3^{\text {rd }}$ edition New York: w.w. Norton and Company, Inc.

Pandey, Sushil Raj (2009). Reflection on security framework of small states: An essay in Journal of Political Science vol xii, No.2 Central Department of Political Science Tribhuvan University, Kritipur, Kathmandu, Nepal.

Panday Sushil Raj (2008). Exploring the terrain of global security (GS): A need for new set of drivers, in Journal of Political Science, vol, xi, No.1, Central Department of Political Science, Trivhuvan University, Kirtipur, Kathmandu Nepal.

Picarelli, John T. (2012). Transitional organized crime in security studies, edited by Paul D. Williams, New York: Routledge Taylor and Francis Group.

Subedi, Surya p. (2010). The challenges to the national security of Nepal and the role of international law and foreign policy in emerging security challenges of Nepal, edited by Rajan Bhattarai and Geja Sharma Wagle, kathmandu: Nepal Institute for Policy Studies (NIPS).

Wagle, Geja Sharma (2010). New challenges for national security in the changed context in emerging security challenges of Nepal, edited by Rajan Bhattarai and Geja Sharma Wagle, Kathmandu: Nepal Institute for policy studies (NIPS).

Williams, Paul D. (2012). Security studies: An introduction in security studies, edited by Paul D .Williams, London: Routledge Taylor and Francis Group. 